University of South Carolina

Scholar Commons

4-1999

\title{
The Value of Open Market Repurchases of Closed-End Fund Shares
}

Gary E. Porter

Rodney L. Roenfeldt

University of South Carolina - Columbia, roenfeldt@moore.sc.edu

Neil W. Sicherman

Follow this and additional works at: https://scholarcommons.sc.edu/fin_facpub

Part of the Finance and Financial Management Commons

\section{Publication Info}

The Journal of Business, Volume 72, Issue 2, 1999, pages 257-276.

http://www.journals.uchicago.edu/JB/home.html

(C) 1999 The University of Chicago

This Article is brought to you by the Finance Department at Scholar Commons. It has been accepted for inclusion in Faculty Publications by an authorized administrator of Scholar Commons. For more information, please contact digres@mailbox.sc.edu. 


\section{Rodney L. Roenfeldt}

University of South Carolina

Neil W. Sicherman

Rollins College

\section{The Value of Open Market Repurchases of Closed-End Fund Shares*}

\section{Introduction}

Why do managers of closed-end funds repurchase shares in the open market? One reason for repurchases frequently espoused by fund managers is to reduce the discount. An example of this rationale is contained in the repurchase announcement for the Pakistan Investment Fund, Inc. The announcement states that "The purpose of the repurchases is to attempt to eliminate the discount to net asset value at which the Fund's shares are currently trading. The Fund will only repurchase its shares at market prices below net asset value. The Fund expects to fund share repurchases out of its existing cash assets", (PR Newswire, March 21, 1994). Similarly, the repurchase announcement for First Australia Fund, Inc. contains the following statement from a broker: "Such stock-repurchase plans 'are

* We are grateful to an anonymous referee, Gordon Alexander, Stan Atkinson, Steven Borde, Roy Brooks, Ronnie Clayton, Jim Gilkeson, Steve Mann, Ted Moore, Pradip Ramanlal, and Jim Wansley for their valuable comments, to Ellen Roueche for excellent research assistance, and to Steen Gilbertson and Don Cassidy of Lipper Analytical and Dan Luchansky of Merrill Lynch Asset Management for providing data.

(Journal of Business, 1999, vol. 72, no. 2)

(C) 1999 by The University of Chicago. All rights reserved.

0021-9398/99/7202-0005\$02.50
We illustrate the value to shareholders when closed-end funds repurchase shares at a discount from net asset value. Repurchases increase share price even when there is no asymmetric information concerning the value of the underlying assets and the percentage discount remains unchanged following the repurchase. Expected gains to shareholders are derived from capturing the discount on the assets associated with the shares repurchased. In an analysis of 27 open market repurchase announcements by closed-end funds, the regression coefficien estimate that measures the association between the actual excess return and the expected increase in share price is essentially 1.0 . 
a very good remedy to cure a persistent discount,' says Thomas Herzfeld, a south Miami, Fla. broker who specializes in closed-end funds", (Dow Jones News Service, January 9, 1987).

Another rationale provided is that an open market share repurchase increases the net asset value per share of the fund for the remaining shareholders. An example of this reasoning is provided in the repurchase announcement for Mexico Fund, Inc., "Jose Luis Gomez Pimienta, President, said the Fund's shares have been trading on the NYSE at a substantial discount from net asset value. "We believe that the stock repurchase program should have a beneficia impact on Fund shareholders by enabling the Fund to acquire its own shares at these favorable discounts, thereby increasing the net asset value per share and the equity of fund shareholders,' he said' (Dow Jones News Service, April 23, 1986). This argument suggests that net asset value per share increases when shares of closed-end funds are repurchased; however, it does not necessarily imply that the percentage discount will decrease after the repurchase is completed.

Signaling is a common explanation provided by academics for the positive share price reaction to repurchase announcements by industrial firms ${ }^{1}$ Signaling theory suggests that reducing information asymmetries between managers and stockholders decreases undervaluation. Unlike an industrial firm there is little information asymmetry concerning the value of a closed-end fund's assets because the underlying asset is a portfolio of marketable securities, and the net asset value is reported weekly (Peavy 1990). Thus, signaling is much less applicable for explaining a share price reaction to open market repurchase announcements of closed-end funds.

We illustrate that share price should increase when fund shares are repurchased at a discount even when there is no asymmetric information concerning the value of the underlying assets. The increase in share price is derived from capturing the discount on the assets associated with the shares repurchased. The magnitude of the expected increase depends only on the percentage discount prior to the announced repurchase and on the percentage of shares to be repurchased. A crucial

1. Other rationales provided for the share price reaction to open market stock repurchase announcements for industrial firm include the tax advantage over cash dividends, an optimal adjustment to the capital structure, wealth expropriation from bondholders to shareholders, and the distribution of excess cash. However, signaling is the most widely accepted rationale for the increase in share price associated with share repurchases (e.g., Vermaelen 1981; Asquith and Mullins 1986; Ofer and Thakor 1987; Constantinides and Grundy 1989; Bartov 1991; Comment and Jarrell 1991; Hausch and Seward 1993; Ikenberry, Lakonishok, and Vermaelen 1995; and Stephens and Weisbach 1998). Recently, Ikenberry and Vermaelen (1996) also propose that the open market repurchase creates valuable flexibilit in the form of an exchange option. We address this argument in our empirical tests for closed-end funds in Section IVC. 
assumption for determining the expected price increase is that the percentage discount remains unchanged after the shares are repurchased. ${ }^{2}$

We analyze a sample of 27 closed-end fund open market repurchase announcements. The average excess return for the closed-end funds is $1.56 \%$ on the announcement of the repurchase. The regression coeffi cient estimate that measures the association between the actual excess return and the expected increase in share price is approximately 1.0. This suggests that the price increase is expected and is associated with the value derived from capturing the discount on the assets of the repurchased shares. We also examine other information effects that may impact the repurchase announcement excess return in addition to the positive effect from capturing the discount. Preannouncement excess returns are related to the announcement period excess returns, but the relationship is positive, which is not consistent with signaling theory (Comment and Jarrell 1991). Proxies for exchange option value (Ikenberry and Vermaelen 1996), trading volume (Sias 1997), and the size of the fund (Ikenberry, Lakonishok, and Vermaelen 1995) are not related to excess returns from closed-end fund share repurchase announcements. After controlling for the preannouncement excess return, exchange option value, trading volume, and size of the fund, however, the coefficien estimate for the relation between the actual excess return and the expected percentage increase in share price remains essentially 1.0 .

The relationship between the expected increase in share price and the discount and percentage of shares to be repurchased also is applicable to open market repurchases by industrial firms A portion of the excess return on the announcement of a repurchase by an industrial fir may be derived from shareholders capturing the discount on the assets associated with the shares repurchased.

Section II contains a discussion of the impact of a share repurchase on the net asset value, market price, and discount of closed-end funds, as well as development of the relationship that provides the expected percentage share price increase. Section III contains a description of the sample selection process and sample characteristics. Section IV provides a discussion of the empirical results and the implications for

2. Our objective is not to provide another explanation for fund discounts that have puzzled financ professionals for many years. Malkiel (1977) reports a cross-sectional relation between discounts and holdings of restricted stock and unrealized capital gains but not with fund performance, portfolio turnover, management fees, payout policy, or holdings of foreign securities. Barclay, Holderness, and Pontiff $(1993,1995)$ report that percentage discounts increase as size of blockholdings friendly to management increase. They attribute this relation to a dominance of entrenchment over a convergence-of-interest. That is, the large blockholders receive pecuniary and nonpecuniary private benefit such as compensation, commissions and fees, voting rights, and promotion of the family name, which they choose to preserve and thus resist any proposals to open-end the fund. 
repurchases by industrial firms Section V contains the summary and conclusions.

\section{Effects of Share Repurchases}

\section{A. Examples of Potential Effects from the Repurchase}

Table 1 contains examples of the effect of a share repurchase at different market prices on the net asset value and discount of a closed-end fund. Before the repurchase, the total net asset value of the fund's portfolio is $\$ 100,000$ with 10,000 shares outstanding, and therefore the net asset value is $\$ 10.00$ per share. The market price per share of the fund is initially $\$ 9.00$ and, thus, the fund sells at a $10 \%$ discount. Four potential outcomes are presented when the fund repurchases $10 \%$ of its outstanding shares. In the firs example, let us assume that the market price per share increases to $\$ 9.091$. After repurchasing the 1,000 shares at the discounted market price of $\$ 9.091$, net asset value per share increases to $\$ 10.101$, and the discount remains at its preannouncement level of $10 \%$. This example illustrates that market price would increase after a repurchase even when the percentage discount remains unchanged. That is, the percentage discount does not have to become smaller after the repurchase is completed for the market price to increase.

The increase in share price occurs because shareholders capture the dollar discount on the assets represented by the repurchased shares. In our example, the fund pays only $\$ 9,091$ to retire claims on $\$ 10,000$ of the fund's assets, and the remaining shareholders claim the other $\$ 909$ in assets. Since the $\$ 909$ in assets is subject to the $10 \%$ discount, the market value of these assets is only $\$ 818$. The total market value of all shares increases by $\$ 909(\$ 91+\$ 818)$, or $\$ 0.091$ per share. Although the fund's assets continue to sell at a 10\% discount, the shareholders capture the dollar discount on the assets that are no longer subject to the discount because of the repurchase.

If the only effect on share price from the repurchase announcement is due to shares being repurchased at a discount, the market price should increase to the level that causes the percentage discount after the shares are repurchased to be the same as before the repurchase announcement. Any additional effect on share price from the announcement would result in a change in market price to more (less) than $\$ 9.091$ and a decrease (increase) in the percentage discount. For example, if the market price increases to $\$ 9.50$ because of additional positive effects unrelated to the gain from capturing the discount, and the 1,000 shares are repurchased at that price, the net asset value per share increases to $\$ 10.056$ and the discount decreases to $5.53 \%$ as shown in table 1 . If the market price per share remains at $\$ 9.00$ because of negative effects that offset the gain from capturing the discount, and the 1,000 shares 


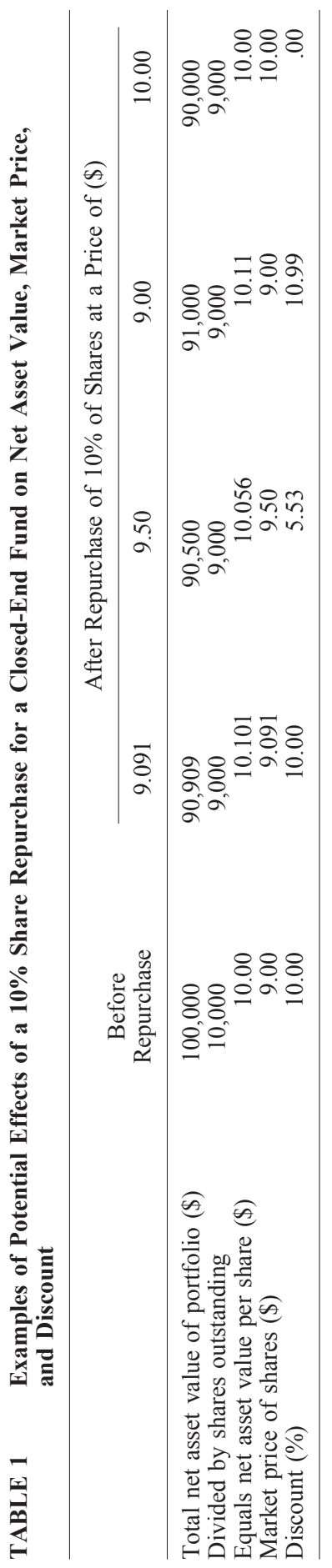


are repurchased at that price, the net asset value per share increases to $\$ 10.11$ and the discount increases to $10.99 \%$. In the fina example, market price per share is assumed to increase to $\$ 10.00$. Repurchases at a market price equal to net asset value do not increase the net asset value per share, and the discount is eliminated. However, closed-end funds announce that they will repurchase shares only at a market price below net asset value.

\section{B. Expected Announcement Effects}

The analysis in this section assumes that the only information conveyed by the repurchase announcement is that the fund will repurchase shares at a price less than net asset value. That is, the only effect on share price is from capturing the dollar discount on the repurchased shares. Therefore, we assume that the percentage discount following the repurchase of shares will be the same as it is before the repurchase announcement. With this assumption, we expect the market price to increase to $\$ 9.091$ in the example presented in table 1 . This expected market price is obtained from the following relationship. ${ }^{3}$

$$
P=\frac{\mathrm{NAV}(1-D)}{1-D R}=\frac{\$ 10(1-.1)}{1-(.1 \times .1)}=\frac{\$ 9}{.99}=\$ 9.091,
$$

where $P$ is the expected market price after the repurchase, NAV and $D$ are the net asset value per share for the fund and the percentage discount before the repurchase announcement, and $R$ is the percentage of shares to be repurchased. ${ }^{4}$

3. The discount $(D)$ after the repurchase is completed is calculated as follows: (new net asset value of the portfolio minus new market value of the fund)/new net asset value of the portfolio. New net asset value of the portfolio equals the net asset value before the repurchase minus the amount of the repurchase [(NAV*S) - $(S * R * P)]$, where NAV and $S$ are the net asset value per share and the number of shares outstanding before the repurchase announcement, $R$ is the percentage of shares to be repurchased, and $P$ is the new market price per share for the fund and the price to be paid for the shares repurchased. New market value of the fund equals the new market price per share of the fund times the shares outstanding after the repurchase $[S *(1-R) * P]$ :

$$
D=\frac{[(\mathrm{NAV} * S)-(S * R * P)]-[S *(1-R) * P]}{(\mathrm{NAV} * S)-(S * R * P)} .
$$

Based on the equation for the discount, the expected new market price for the fund and the price to be paid for the shares repurchased can be expressed as a function of the discount, the percentage of shares to be repurchased, and the net asset value per share:

$$
P=\frac{\mathrm{NAV}(1-D)}{1-D R} .
$$

4. If net asset value represents the true value of the fund's shares, fund managers will not have superior information relative to investors during the life of the repurchase program. In this sense, the value of the repurchase exchange option as proposed by Ikenberry and Vermaelen (1996) is zero for closed-end funds. Similarly, if the percentage discount remains constant after the repurchase, this implies that the correlation between the returns on the fund's shares and the returns on the true value as measured by net asset value is 1.0. Under these conditions, the value of the repurchase exchange option also is zero. How- 
The expected percentage change in market price for the fund can be determined from the market price before the repurchase announcement and the expected market price after the repurchase. For our example, the expected price change from $\$ 9.00$ to $\$ 9.091$ is $1.01 \%$. This expected return $(\Delta P / P)$ can be expressed as a function of $D$ and $R$ only. ${ }^{5}$

$$
\begin{aligned}
\Delta P / P & =D R /(1-D R)=(.1 \times .1) /(1-(.1 \times .1)) \\
& =.01 / .99=1.01 \% .
\end{aligned}
$$

The expected return is positive when a fund sells at a discount. For relatively small values of $D$ and $R$, the expected return is approximately equal to the product of the discount and the percentage of shares to be repurchased.

The expected return from the repurchase contains three important implications. ${ }^{6}$ First, the expected return is larger the larger the percentage discount before the announcement. Second, the expected return is larger the larger the percentage of shares to be repurchased. Third, the expected return increases at an increasing rate as either the percentage discount before the repurchase announcement or the percentage of shares to be repurchased becomes larger. For example, if the shares in the example in table 1 initially sell at $\$ 8.00$ rather than $\$ 9.00$, the discount is $20 \%$ before the repurchase announcement. If $10 \%$ of the shares are repurchased, the expected market price is $\$ 8.163$ from equation (1), and equation (2) provides the expected return of $2.04 \%$. The $2.04 \%$ expected return is more than twice as large as the $1.01 \%$ expected return for a $10 \%$ discount. Similarly, if the initial market price is $\$ 9.00$ and

ever, if the percentage discount is expected to increase for any reason before the repurchase program is terminated, the repurchase exchange option may have value because the fund could repurchase shares at an even greater discount than exists at the time of the announcement. If the exchange option has value, the market price of the fund may increase to more than the expected price based on equation (1). Conversely, if the repurchase announcement increases the bid-ask spread because of potential trading by an informed trader (the fund), the expected price will be smaller than that given in equation (1) (Barclay and Smith 1988).

5. The discount $(D)$ before the repurchase is (NAV $\left.-P^{*}\right) / \mathrm{NAV}$, where NAV and $P^{*}$ are the net asset value per share and the market price per share before the repurchase announcement. Solving for $P^{*}, P^{*}=\mathrm{NAV}(1-D)$. The expected percentage change in price $(\Delta P / P)$ is computed from the price before the announcement $\left(P^{*}\right)$ and the expected price after the announcement $(P):\left(P-P^{*}\right) / P^{*} . \Delta P / P$ also can be expressed as a function only of the discount before the repurchase announcement and the percentage of shares to be repurchased:

$$
\begin{aligned}
\Delta P / P & =\frac{\frac{\operatorname{NAV}(1-D)}{1-D R}-\mathrm{NAV}(1-D)}{\mathrm{NAV}(1-D)} \\
\Delta P / P & =D R /(1-D R) .
\end{aligned}
$$

6. A formal representation of these implications is shown as: $\partial(\Delta P / P) / \partial D>0$; $\partial(\Delta P / P) / \partial R>0 ;$ and $\partial^{2}(\Delta P / P) / \partial D^{2}>0, \partial^{2}(\Delta P / P) / \partial R^{2}>0$. 
the discount before the announcement is $10 \%$, but the fund repurchases $20 \%$ of its shares, equation (1) reveals that the market price will increase to $\$ 9.184$ and equation (2) provides the $2.04 \%$ expected return. The $2.04 \%$ expected return from a $20 \%$ repurchase is more than twice as large as the $1.01 \%$ expected return from the $10 \%$ repurchase.

With rational investors, the expected price increase should occur on the announcement of the repurchase. Until the shares are actually repurchased, however, the net asset value per share does not change, and the percentage discount decreases temporarily. For our example with an initial market price of $\$ 9.00$, the net asset value remains at $\$ 10.00$ on the announcement of the repurchase, but the market price increases to $\$ 9.091$ and the discount decreases to $9.09 \%$. After the shares are repurchased at the market price of $\$ 9.091$, the net asset value per share increases to $\$ 10.101$, and the discount increases to $10 \%$, its level before the repurchase announcement. Therefore, the wealth gain for shareholders on the announcement of the repurchase is not caused by a permanent decrease in the percentage discount. The increase in share price occurs because the dollar discount on the assets associated with the repurchased shares is captured by the shareholders. The expected wealth gain for shareholders is similar to that of open-ending a portion of the shares (Brickley and Schallheim 1985).

In summary, the expected return from a repurchase announcement for a closed-end fund depends entirely on the size of the percentage discount before the announcement and the percentage of shares to be repurchased when the only effect on share price is from buying shares at a discount. Market price is expected to increase on the announcement of the repurchase for funds selling at a discount, and the increase in market price should be larger the larger the discount before the announcement and the larger the percentage of shares to be repurchased. Since net asset value per share does not increase on the announcement, the percentage discount should temporarily decrease on the announcement of the repurchase. After the shares are repurchased, the net asset value per share increases, and the discount increases to the percentage level that existed before the repurchase announcement.

Equation (2) provides testable implications for the effect of the repurchase announcement on the market price of a closed-end fund. For a closed-end fund selling at a discount, the announcement of an open market repurchase is expected to be associated with a positive share price response when the announcement does not permanently change the percentage discount. Also, the actual percentage increase in market price should equal the expected return from equation (2) if the only price effect from the repurchase announcement is associated with the gain to shareholders from capturing the dollar discount on the shares repurchased. 


\section{Sample Selection and Characteristics}

Using the investment company funds listed on the Center for Research in Security Prices (CRSP) files the Dow Jones News/Retrieval text database was searched from 1979-95. Press releases for these funds coded as buy back by Dow Jones were screened to include only announcements of open market repurchases. An initial sample of 48 open market common stock repurchase announcements was obtained for closed-end funds.

The sample was further reduced because (1) four funds did not release information about the amount of shares to be repurchased, (2) eight announcements were associated with other information about the fund being released during the three-day period around the announcement, (3) fiv announcements were by funds that did not have sufficien returns on the CRSP file to conduct the analysis, and (4) four funds sold at a premium. ${ }^{7}$ The fina sample includes 27 open market repurchase announcements between 1986-94 by closed-end funds selling at a discount. A list of the funds and the announcement dates are provided in the appendix. Of the 27 announcements, 17 are by bond funds, eight are by equity funds, and two are by balanced funds. Seven of the announcements are by funds investing in international securities. The announcements are made by 21 different funds on 18 different announcement dates. ${ }^{8}$ Fund data for net asset value per share, market price per share, and the discount were obtained from the Wall Street Journal, Lipper Analytical Services, Inc., and the closed-end funds.

Table 2 contains values for several variables that help describe the 27 closed-end funds in the sample. The maximum percentage of shares to be repurchased averages $9.44 \% .^{9}$ The percentage to be repurchased ranges from $3.18 \%$ to $26.67 \%$ for the funds. The essence of most of the repurchase announcements is provided in the following statement contained in the announcement by the Growth Fund of Spain, Inc.: "The company said that repurchases will only be made when the Fund's shares are trading at less than net asset value and at such times and amounts as is believed to be in the best interest of the Fund's shareholders"' (Dow Jones News Service, April 26, 1990). Only three

7. We excluded the four funds selling at a premium because they announced that they would only repurchase shares at a price below net asset value. Since these funds will only repurchase shares selling at a discount, but the shares are currently selling at a premium, equation (2) is not strictly applicable.

8. To examine the influenc of event date clustering, the analysis was replicated without the seven MSF funds with an announcement on May 25, 1990. The results are essentially unchanged.

9. This percentage is slightly greater than the $5 \%, 6.6 \%$, and $7 \%$ reported by Dann (1980), Ikenberry, Lakonishok, and Vermaelen (1995), and Stephens and Weisbach (1998), respectively, for samples of open market repurchase announcements for industrial firms 
TABLE 2 Sample Characteristics for 27 Open Market Repurchases for Closed-End Funds for 1986-94

\begin{tabular}{|c|c|c|c|c|}
\hline Variable & Mean & Median & Low & High \\
\hline Maximum shares to be repurchased (\%) & 9.44 & 5.00 & 3.18 & 26.67 \\
\hline $\begin{array}{l}\text { Shares repurchased subsequent to announce- } \\
\text { ment }(\%)^{*, \dagger}\end{array}$ & 7.87 & 3.33 & .00 & 68.18 \\
\hline Market value of equity (millions of dollars) & 434.09 & 177.84 & 44.06 & $1,525.14$ \\
\hline Shares outstanding (millions) & 56.51 & 24.18 & 3.75 & 200.25 \\
\hline Price per share $(\$)$ & 8.36 & 8.13 & 3.00 & 11.75 \\
\hline $\begin{array}{l}\text { Discount for week prior to announce- } \\
\text { ment }(\%)\end{array}$ & 10.76 & 9.27 & .84 & 29.10 \\
\hline $\begin{array}{l}\text { Discount } 8 \text { weeks prior to announce- } \\
\text { ment }(\%)\end{array}$ & 6.64 & 7.98 & $-52.00 \ddagger$ & 50.00 \\
\hline $\begin{array}{l}\text { Change in discount over } 8 \text { weeks prior to } \\
\text { announcement (basis points } / 100 \text { ) }\end{array}$ & 4.12 & 2.21 & -32.64 & 62.56 \\
\hline
\end{tabular}

* Shares repurchased are based on annual or semiannual reports file with the SEC for the fisca year in which the announcement was made and for the subsequent fisca year.

$\dagger$ Pilgrim Prime Rate Trust announced a plan to repurchase $10 \%$ of the outstanding shares in the open market but repurchased $68.18 \%$ by the fisca year end following the announcement. Without the Pilgrim repurchase, the mean (median) amount repurchased was 5.55\% (3.31\%), and the maximum was $27.83 \%$.

$\ddagger$ A negative discount represents a premium.

funds specifie the time period for the repurchases, and almost all of the announcements specificall state or imply that the repurchases will be made only when the shares are selling at a discount from net asset value.

Since management is not obligated to repurchase shares, we examined the funds' annual or semiannual reports file with the SEC for the fisca year in which the announcement was made and for the subsequent fisca year to determine how many shares were repurchased. Repurchases occurred following 25 of the 27 announcements. Based on the annual reports, a mean (median) of $7.87 \%(3.33 \%)$ of the outstanding shares was repurchased. By the end of the second fisca year following the announcement, on average the funds had repurchased $79 \%$ of the shares stated in the announcement as the maximum to be repurchased. ${ }^{10}$

The market value of the funds averages $\$ 434.09$ million with an average of 56.51 million shares outstanding. The share prices for the funds are relatively low, ranging from a low of $\$ 3.00$ to a high of $\$ 11.75$ with a mean of $\$ 8.36$. The discount for the fund's market price as a percentage of net asset value averages $10.76 \%$ prior to the repurchase announcement. The largest discount is $29.10 \%$. On average,

10. Funds occasionally extend the repurchase program beyond the maximum shares originally announced for repurchase. Pilgrim Prime Rate repurchased $68 \%$ of the outstanding shares following the announcement to repurchase up to $10 \%$. Excluding Pilgrim, the other 26 announcements were followed by repurchases representing an average of $57 \%$ of the shares announced for repurchase. 
discounts became larger during the 8 weeks prior to the repurchase announcement. The average discount increases 412 basis points from $6.64 \% 8$ weeks prior to the announcement to $10.76 \%$ in the announcement week. The discount grew larger during the 8 weeks prior to the repurchase announcement for 18 of the funds $(67 \%)$ and became smaller for only nine of the funds (33\%).

\section{Results}

\section{A. Excess Returns}

The market model is used to measure excess returns associated with the 27 open market repurchase announcements for the closed-end funds. The day of the repurchase announcement is define as $t=0$. The market model parameters are estimated over the 160-day period from $t=+41$ to $t=+200$ using the CRSP equally weighted index.

The cumulative average excess return for the 27 funds for the 2-day announcement period $(t=0,+1)$ is $1.56 \%$ with a $z$-value of 3.87 using the parametric test based on standardized excess returns (Mikkelson and Partch 1988). We also test the significanc of the excess return using the nonparametric rank test introduced in Corrado (1989) and the rank statistic is 3.07 for the 2-day excess return. Although positive and significant the 2-day excess return is somewhat smaller than the excess returns of $2.3 \%$ to $3.5 \%$ for 2- to 5 -day periods for open market repurchase announcements for industrial firm reported by Dann (1980), Vermaelen (1981), Comment and Jarrell (1991), Ikenberry, Lakonishok, and Vermaelen (1995), and Stephens and Weisbach (1998). Nineteen $(70 \%)$ of the excess returns are positive and eight $(30 \%)$ are negative. The excess returns range from a low of $-2.38 \%$ to a high of $9.69 \%$.

\section{B. Expected Return}

Equation (2) yields the expected return for each closed-end fund on the repurchase announcement, assuming there is no information conveyed by the repurchase announcement that permanently changes the percentage discount after the shares are repurchased. A comparison of the expected return with the actual excess return enables us to make some inferences concerning the degree to which the actual excess return is associated with the magnitude of the discount and the percentage of shares to be repurchased.

The average expected return from equation (2) for the 27 closed-end funds is $1.33 \% .{ }^{11}$ We regress the announcement period excess return on

11. Since the net asset values and discounts for closed-end funds are only reported weekly for the Friday close, we cannot determine the expected price increase for the day of the announcement. We obtain net asset values, market prices, and discounts for the closed-end funds for the Friday prior to the announcement. Occasionally, the data are 
TABLE 3 Relation between Prediction Errors on Announcement of the Repurchase of Shares and the Expected Return Based on the Discount and Percentage of Shares to Be Repurchased for 27 Closed-End Funds for 1986-94

\begin{tabular}{lcc}
\hline & Model 1 & Model 2 \\
\hline Intercept & .005 & -.015 \\
& $(.84)$ & $(-.63)$ \\
Expected return* & .828 & .921 \\
& $(2.98)$ & $(3.07)$ \\
Log of fund market value of equity & $\times \times \times$ & .003 \\
& $\times \times \times$ & $(.85)$ \\
$F$-value & 8.87 & 4.75 \\
Adjusted $R^{2}$ & .23 & .22 \\
\hline
\end{tabular}

NotE. The results are OLS regression coefficien estimates with $t$-values in parentheses. The dependent variable is the 2-day prediction error around the open market repurchase announcement.

* The expected return is determined from the following equation:

$$
\Delta P / P=D R /(1-D R),
$$

where $D$ is the percentage discount before the repurchase announcement and $R$ is the percentage of shares to be repurchased.

the expected return for the 27 funds. Model 1 in table 3 provides the results. The coefficien estimate for the expected return is $0.828(t=$ 2.98). This coefficien estimate is not statistically different from 1.0 $(t=-0.62) .{ }^{12}$ For each $1 \%$ increase in the expected return from equation (2), the excess return on the announcement of the repurchase also increases about $1 \%$, on average.

Model 2 in table 3 replicates model 1 but includes a control variable for the size of the closed-end fund. The size of the fund is measured as the log of the market value of equity on the day before the repurchase announcement. The coefficien estimate for the expected return is 0.921 $(t=3.07)$. Again, the coefficien estimate is not statistically different from $1.0(t=-0.26)$. The strong relation between the actual excess return and the return expected from equation (2) continues even after controlling for the size of the fund. The coefficien estimate for the size of the fund is not significantl different from zero $(0.003 ; t=0.85)$.

reported for the Thursday close. We calculate the expected percentage price increase using equation (2) for each fund as if the repurchase announcement occurred on the day for which we obtain the discount. This, of course, introduces a small measurement error because the discount may change slightly from the day for which we obtain the discount to a week later, in some cases, when the repurchase announcement occurs.

12. Since outliers in a small sample may influenc the estimated set of coefficients we examine Cook's $D$-statistic (Cook 1977, 1979) for each observation. None of the $D$-statistics is significan at the .05 level, suggesting that the coefficien estimates in models 1 and 2 of table 3 are not unduly influence by any single repurchase announcement. 
Ikenberry et al. (1995) fin a negative relation between announcement period excess returns and the size variable for industrial firms

This analysis suggests that the percentage price increase for the sample of closed-end funds from the announcement of the repurchase of shares is expected based on equation (2) and is directly related to the magnitude of the percentage discount before the announcement and the percentage of shares to be repurchased. That is, excess returns from repurchase announcements are associated with the value derived from capturing the discount on the assets represented by the repurchased shares.

Also of interest is the change in the discount on the announcement of the repurchase. A temporary decrease in the discount on the announcement is expected because the market price increases on the announcement of the repurchase, and the net asset value per share does not increase until the shares are actually repurchased. Discounts are only reported weekly, which prevents measuring the change in the discount on the announcement date. However, we can measure the change in the discount from the Friday close before the announcement to the Friday close after the announcement.

The discounts for the 27 closed-end funds average $10.8 \%$ before the announcements. Based on the expected market price calculated from equation (1) for each fund for the Friday before the announcement, the discount is expected to decrease temporarily from $10.8 \%$ to $9.7 \%$ after the announcement. That is, we expect the average discount to decrease by 110 basis points based only on the size of the discount before the announcement and percentage of shares to be repurchased. One week later when we observe the discounts subsequent to the repurchase announcement, the average discount is $9.5 \%$, a decrease of 130 basis points. Although our measurement of the actual change in the discount after the repurchase announcement is imprecise because it is measured over one week rather than only for the day of the announcement, the expected and actual changes in the discounts do not differ significantl $(t=0.38)$. Both the increase in market price per share and the decrease in the percentage discount on the announcement of the repurchase appear to be related directly to the size of the discount before the repurchase announcement and the percentage of shares announced to be repurchased.

The expected return from equation (2) assumes there is no information conveyed in the repurchase announcement that permanently changes the percentage discount after the shares are repurchased. A direct test for other price effects associated with the repurchase announcement would be to measure the change in the discount when the shares are actually repurchased. If the only effect on the share price is the expected return from equation (2), the decrease in the discount on the announcement of the repurchase should be temporary. When the 
shares are actually repurchased, the net asset value per share increases, and the discount increases to the percentage that existed prior to the announcement. Since the dates of the open market repurchases are not reported, and the repurchases occur in small quantities over time, no one date can be used to measure the impact of the actual repurchase. In addition, measurement of the discount weeks or months subsequent to the announcement would contain information that is unrelated to the effect from the actual repurchases. Thus, measuring the change in the discount from the day after the repurchase announcement to some arbitrary date in the future would not indicate the impact of the actual repurchase of the shares on the discount. Thus, indirect tests are necessary to detect any other price effects associated with the announcement. The following section contains an analysis of additional price effects that may be associated with the excess return on announcement of a repurchase.

\section{Additional Price Effects}

Excess returns prior to the announcements are frequently associated with excess returns from repurchase announcements for industrial firms Model 1 in table 4 provides an estimate of the relation between the 2-day excess return on the announcement of the repurchase for closed-end funds and excess return for the 40 days prior to the announcement. ${ }^{13}$ The positive coefficien estimate for the preannouncement period excess return $(0.094 ; t=2.30)$ is different from the negative relation reported by Comment and Jarrell (1991) for industrial firms We do not have an explanation for this result, but the result is not consistent with the typical signaling explanation for excess returns for industrial firms The coefficien estimate for the expected return from equation (2) based on the discount and percentage of shares to be repurchased remains positive $(0.904 ; t=3.27)$ and not statistically different from $1.0(t=-0.35) .{ }^{14}$

Ikenberry and Vermaelen (1996) model open market share repurchase programs as options for firm to buy back shares when they trade below true value. The exchange option value is related to the volatility of the underlying shares and the percentage of the shares outstanding authorized for repurchase. The percentage authorized for repurchase is a key variable in our equation (2). ${ }^{15}$ Following Ikenberry

13. Tests for heteroskedasticity suggest that no adjustments are required for any of the models in table 4 (White 1980).

14. Cook's $D$-statistic (Cook 1977, 1979) is examined for each observation in models $1-4$ of table 4 . Only one observation in models 3 and 4 has a $D$-statistic significan at the .05 level. The models were reestimated with this observation omitted, and the coefficien estimates are essentially unchanged.

15. The residuals from model 1 in table 3 are regressed against the percentage of shares to be repurchased $(R)$ and the discount $(D)$ to determine whether these variables are associated with the actual excess returns beyond their relationship given by equation (2). The results of the regression are 
TABLE 4 Relation between Prediction Errors on Announcement of the Repurchase and Expected Return Based on the Discount and Percentage of Shares to Be Repurchased, Preannouncement Period Excess Return, Market Model $R^{2}$, Standard Deviation of Market Returns, Trading Volume Relative to Shares to Be Repurchased, and Market Value of Equity for Open Market Repurchase Announcements for 27 Closed-End Funds for 1986-94

\begin{tabular}{|c|c|c|c|c|}
\hline & Model 1 & Model 2 & Model 3 & Model 4 \\
\hline Intercept & $\begin{array}{l}-.019 \\
(-.87)\end{array}$ & $\begin{array}{l}-.011 \\
(-.35)\end{array}$ & $\begin{array}{l}-.020 \\
(-.80)\end{array}$ & $\begin{array}{l}-.015 \\
(-.53)\end{array}$ \\
\hline Expected return* & $\begin{array}{r}.904 \\
(3.27)\end{array}$ & $\begin{array}{r}.941 \\
(2.89)\end{array}$ & $\begin{array}{r}.978 \\
(3.13)\end{array}$ & $\begin{array}{r}1.072 \\
(3.52)\end{array}$ \\
\hline $\begin{array}{l}\text { Preannouncement period ex- } \\
\text { cess return }\end{array}$ & $\begin{array}{r}.094 \\
(2.30)\end{array}$ & $\cdots$ & $\begin{array}{l}\cdots \\
\ldots\end{array}$ & $\begin{array}{r}.112 \\
(2.45)\end{array}$ \\
\hline Market model $R^{2}$ & a & $\begin{array}{l}-.008 \\
(-.19)\end{array}$ & $\begin{array}{l}\cdots \\
\cdots \\
\cdots\end{array}$ & $\begin{array}{r}.008 \\
(.19)\end{array}$ \\
\hline Standard deviation of returns & $\begin{array}{l}\cdots \\
\cdots\end{array}$ & $\begin{array}{l}-.094 \\
(-.12)\end{array}$ & $\begin{array}{l}\cdots \\
\cdots\end{array}$ & $\begin{array}{l}-.496 \\
(-.68)\end{array}$ \\
\hline $\begin{array}{l}\text { Trading volume/shares to be } \\
\text { repurchased }\end{array}$ & $\cdots$ & $\cdots$ & $\begin{array}{l}.085 \\
(.74)\end{array}$ & $\begin{array}{r}.160 \\
(1.27)\end{array}$ \\
\hline $\begin{array}{l}\text { Log of fund market value of } \\
\text { equity }\end{array}$ & $\begin{array}{r}.004 \\
(1.17)\end{array}$ & $\begin{array}{l}.003 \\
(.67)\end{array}$ & $\begin{array}{l}.003 \\
(.87)\end{array}$ & $\begin{array}{l}.003 \\
(.85)\end{array}$ \\
\hline $\begin{array}{l}F \text {-value } \\
\text { Adjusted } R^{2}\end{array}$ & $\begin{array}{r}5.49 \\
.34\end{array}$ & $\begin{array}{r}2.23 \\
.16\end{array}$ & $\begin{array}{r}3.29 \\
.21\end{array}$ & $\begin{array}{r}3.08 \\
.32\end{array}$ \\
\hline
\end{tabular}

NotE. The results are OLS regression coefficien estimates with $t$-values in parentheses. The dependent variable is the 2-day prediction error around the open market repurchase announcement.

* The expected return is determined from the following equation:

$$
\Delta P / P=D R /(1-D R)
$$

where $D$ is the percentage discount before the repurchase announcement and $R$ is the percentage of shares to be repurchased.

and Vermaelen (1996), we capture the systematic and unique components of volatility of the underlying shares by measuring the $R^{2}$ from the market model and the standard deviation of share returns for each fund. The results from model 2 reported in table 4 suggest that the exchange option value is not associated with the excess returns in our sample of closed-end funds after controlling for the expected return. Since the discount for closed-end funds is observable (in contrast to the industrial firm studied by Ikenberry and Vermaelen), the option value may be negligible. The coefficien estimate for the expected return remains not statistically different from $1.0(t=-0.18)$.

Another aspect of the repurchase that may influenc the price reac-

$$
\begin{aligned}
\text { Residual }= & -0.000-0.091 D-0.103 R . \\
& (-0.02)(-1.05) \quad(-1.14)
\end{aligned}
$$

These results imply that these two variables have no significan impact on the excess return beyond that captured in the expected return from equation (2). 
tion for a closed-end fund is the impact of price pressure and/or the change in liquidity for the fund after the repurchase (Sias 1997). At least two countervailing forces are at work here. First, authorization of a repurchase temporarily increases the potential demand for shares relative to the supply of shares. This potential increase in demand could increase temporarily the price of the fund's shares relative to the net asset value per share and, correspondingly, decrease the discount. In this case, we would expect funds with smaller trading volume relative to shares planned to be repurchased to have greater increases in market price on the repurchase announcement than would funds with larger trading volume relative to shares to be repurchased. ${ }^{16}$ A counterargument is that share repurchases are perceived as a potential permanent reduction in trading volume and liquidity because fewer shares will be outstanding. ${ }^{17}$ This perceived reduction in liquidity could result in a smaller price increase or price decline relative to net asset value per share and a corresponding increase in the discount. If this is a dominant influence we would expect funds with smaller trading volume relative to shares planned to be repurchased to have smaller price increases than expected from equation (2) compared with funds with larger trading volume relative to shares to be repurchased.

We measure trading volume as the average daily number of shares traded for the 45 days prior to the repurchase announcement to reduce the influenc of any unusually low or high volume for any one day or week. Model 3 in table 4 contains the results of the estimated relation between the 2-day excess return on the announcement of the repurchase and the trading volume relative to shares to be repurchased. The coefficien estimate is positive $(0.085)$ but not significantl different from zero $(t=0.74) .{ }^{18}$ This suggests that trading volume relative to shares to be repurchased either is not associated with the excess return on the announcement of a repurchase, or the potential impacts from the

16. SEC regulations designed to prevent firm from materially influencin volume and price suggest that price pressure may not be a dominant factor.

17. The price change on announcement of a repurchase also may be affected by market microstructure issues. If informed traders enter the market, the bid-ask spread should increase resulting in a reduction in liquidity. Barclay and Smith (1988) report evidence consistent with an increase in the spread subsequent to a repurchase announcement. More recent studies by Miller and McConnell (1995), Wiggins (1994), and Singh, Zaman, and Krishnamurti (1994) all conclude that the bid-ask spread does not change. SEC Rule 10618 restricts a firm' repurchase activity in terms of its effect on price and volume. This rule may reduce any potential influenc the repurchase announcement may have on the spread. In addition, if the net asset value of a fund represents its true value, asymmetric information is substantially reduced and a closed-end fund may be considered less of an informed trader than an industrial firm We do not directly analyze the impact of a repurchase announcement on the bid-ask spread for the closed-end funds.

18. Because the ratio of trading volume relative to shares to be repurchased is signifi cantly correlated with the expected return, we also regressed the residuals obtained from model 1 , table 3 on trading volume relative to shares to be repurchased. The results are essentially the same as those reported in table 4. 
repurchase are offsetting after controlling for the expected return. The coefficien estimate for the expected return remains not statistically different from $1.0(t=-0.07)$.

Model 4 in table 4 includes all the variables. The coefficien estimate for expected return remains not statistically different from $1.0(t=$ $0.24)$. After controlling for preannouncement period excess return, the exchange option value, trading volume, and the size of the fund, a $1 \%$ increase in the expected return from equation (2) is associated with a $1 \%$ increase in the excess return on announcement of the repurchase.

\section{Implications for Industrial Firms}

The expected return provided by equation (2) has implications for open market repurchases by industrial firms A portion of the excess return on the announcement of a repurchase by an industrial fir may be due to the expected return from capturing the discount on the assets associated with the shares repurchased. Of course, testing this implication for industrials is more difficul because, unlike closed-end funds, the true value of the firm' assets must be estimated, and the percentage discount may change permanently after the repurchase due to an undervaluation signal.

The difficult in measuring the discount, however, does not reduce the applicability of equation (2) to open market repurchases by industrial firms The ratio of market value of the fir to replacement value of assets, or Tobin's Q, may be a sufficien proxy to use for the discount for testing whether the expected return from equation (2) is associated with the actual excess return for open market repurchase announcements by industrial firms

\section{Summary and Conclusions}

We show that the market price of a closed-end fund should increase even when the only information conveyed by the repurchase announcement is that the fund will repurchase shares at a discount from net asset value. The percentage increase only depends on the percentage discount from net asset value before the repurchase announcement and the proportion of shares outstanding announced to be repurchased. The value to shareholders occurs from capturing the discount on the assets associated with the shares repurchased. More value occurs the greater the discount and the greater the proportion of shares repurchased at the discounted price when the percentage discount does not change after the shares are repurchased.

For a sample of 27 closed-end funds, the average 2-day announcement excess return is $1.56 \%$. The regression model estimates indicate that for each increase of $1 \%$ in the return expected, based only on the preannouncement discount and the percentage of shares announced to 
be repurchased, the actual excess return on the announcement also increases $1 \%$. Since market price increases when a repurchase program is announced and net asset value per share does not increase until shares are actually repurchased, the discount temporarily decreases on the announcement of the repurchase. For the 27 closed-end funds, the expected average decrease in the discount is 110 basis points compared to the actual decrease of 130 basis points.

We examine other effects that may be associated with the excess returns. We fin that preannouncement excess returns are positively related to announcement period excess returns for closed-end funds. We also fin that proxies associated with the exchange option value examined by Ikenberry and Vermaelen (1996) do not explain closedend fund repurchase announcement excess returns. In addition, we do not fin evidence that either an increase in demand or reduction in longterm liquidity from the repurchase announcement is a dominant factor associated with the excess return from the announcement of the repurchase. However, after controlling for these factors and the size of the fund, the coefficien estimate remains essentially 1.0 for the relation between the actual excess return and the return expected based only on the discount and percentage of shares to be repurchased.

We conclude that closed-end funds may repurchase shares because of the expected wealth gain for shareholders. The wealth increase results from elimination of the discount on the assets associated with the repurchased shares. The price increase is expected based only on the percentage discount before the repurchase announcement and the percentage of shares to be repurchased.

The relationship illustrated for closed-end funds also is applicable to open market repurchases by industrial firms Although repurchase announcements by industrial firm may be a way for management to signal undervaluation, firm that continue to sell at discounts also can enhance value for shareholders by purchasing their shares at a discount. We may be able to identify the component of the excess returns for industrial firm associated with capturing the discount on the assets associated with the shares repurchased. 


\section{Appendix}

\section{Closed-End Funds and Open Market Repurchase Announcement Dates}

Name

Charles Allmon Trust, Inc.

Delaware Group Div \& Income

First Australia Fund, Inc.

First Boston Income Fund, Inc.

First Boston Strategic Income Fund, Inc.

Growth Fund of Spain, Inc.

Hyperion 2005 Investment Grade Opportunity Term Trust, Inc.

Hyperion Total Return Fund, Inc.

Lincoln National Convertible Securities Fund

Mexico Fund, Inc.

MFS Charter Income Trust SBI

MFS Charter Income Trust SBI

MFS Government Markets Income Trust

MFS Government Markets Income Trust

MFS Government Markets Income Trust

MFS Income and Opportunity Trust

MFS Intermediate Income Trust

MFS Intermediate Income Trust

MFS Multimarket Income Trust

MFS Multimarket Income Trust

MFS Multimarket Income Trust

MFS Multimarket Total Return Trust

MFS Special Value Trust

Nicholas-Applegate Growth Equity Fund, Inc.

Pakistan Investment Fund, Inc.

Pilgrim Prime Rate Trust

Zweig Fund
Announcement Date

April 29, 1992

December 20, 1994

January 9, 1987

December 12, 1990

December 12, 1990

April 26, 1990

June 15, 1993

August 18, 1993

December 4, 1987

April 23, 1986

May 25, 1990

November 4, 1994

May 25, 1990

August 12, 1993

November 4, 1994

May 25, 1990

May 25, 1990

August 12, 1993

May 25, 1990

July 21, 1993

November 16, 1994

May 25, 1990

May 25, 1990

December 14, 1987

March 21, 1994

July 17, 1992

April 14, 1987

\section{References}

Asquith, P., and Mullins, D. W., Jr. 1986. Signaling with dividends, stock repurchases, and equity issues. Financial Management 15 (Autumn): 27-44.

Barclay, M. J.; Holderness, C. G.; and Pontiff, J. 1993. Private benefit from block ownership and discounts on closed-end funds. Journal of Financial Economics 33 (June): 263-91.

Barclay, M. J.; Holderness, C. G.; and Pontiff, J. 1995. Concentrated ownership and discounts on closed-end funds. Journal of Applied Corporate Finance 8 (Spring): 32-42.

Barclay, M. J., and Smith, C. W., Jr. 1988. Corporate payout policy: Cash dividends versus open-market repurchases. Journal of Financial Economics 22 (October): 61-82.

Bartov, E. 1991. Open-market stock repurchases as signals for earnings and risk changes. Journal of Accounting and Economics 14 (September): 275-94.

Brickley, J. A., and Schallheim, J. S. 1985. Lifting the lid on closed-end investment companies: A case of abnormal returns. Journal of Financial and Quantitative Analysis 20 (March): 107-17.

Comment, R., and Jarrell, G. A. 1991. The relative signaling power of Dutch auction and fixed-pric self-tender offers and open-market share repurchases. Journal of Finance 46 (September): 1243-71.

Constantinides, G. M., and Grundy, B. D. 1989. Optimal investment with stock repurchase and financin as signals. Review of Financial Studies 2, no. 4:445-65.

Cook, R. D. 1977. Detection of influentia observations in linear regression. Technometrics 19 (February): 15-18. 
Cook, R. D. 1979. Influentia observations in linear regression. Journal of the American Statistical Association 74 (March): 169-74.

Corrado, C. J. 1989. A nonparametric test for abnormal security-price performance in event studies. Journal of Financial Economics 23 (August): 385-95.

Dann, L. Y. 1980. The effect of common stock repurchases in securityholder returns. Ph.D. dissertation, University of California, Los Angeles.

Hausch, D. B., and Seward, J. K. 1993. Signaling with dividends and share repurchases: A choice between deterministic and stochastic cash disbursements. Review of Financial Studies 6(1): 121-54.

Ikenberry, D.; Lakonishok, J.; and Vermaelen, T. 1995. Market underreaction to open market share repurchases. Journal of Financial Economics 39 (October-November): 181-208.

Ikenberry, D., and Vermaelen, T. 1996. The option to repurchase stock. Financial Management 25 (Winter): 9-24.

Malkiel, B. G. 1977. The valuation of closed-end investment company shares. Journal of Finance 32 (June): 847-59.

Mikkelson, W. H., and Partch, M. M. 1988. Withdrawn security offerings. Journal of Financial and Quantitative Analysis 23 (June): 119-33.

Miller, J. M., and McConnell, J. J. 1995. Open-market share repurchase programs and bidask spreads on the NYSE: Implications for corporate payout. Journal of Financial and Quantitative Analysis 30 (September): 365-82.

Ofer, A. R., and Thakor, A. V. 1987. A theory of stock price response to alternative corporate disbursement methods: Stock repurchases and dividends. Journal of Finance 42 (June): $365-94$.

Peavy, J. W., III. 1990. Returns on initial public offerings of closed-end funds. Review of Financial Studies 3, no. 4: 695-708.

Sias, R. W. 1997. Price pressure and the role of institutional investors in closed-end funds. Journal of Financial Research 20 (Summer): 211-29.

Singh, A. K.; Zaman, M. A.; and Krishnamurti, C. 1994. Liquidity changes associated with open market repurchases. Financial Management 23 (Spring): 47-55.

Stephens, C. P., and Weisbach, M. S. 1998. Actual share reacquisitions in open-market repurchase programs. Journal of Finance 53 (February): 313-33.

Vermaelen, T. 1981. Common stock repurchases and market signalling: An empirical study. Journal of Financial Economics 9 (June): 139-83.

White, H. 1980. A heteroskedasticity-consistent covariance matrix estimator and a direct test for heteroskedasticity. Econometrica 48 (May): 817-38.

Wiggins, J. B. 1994. Open market stock repurchase programs and liquidity. Journal of Financial Research 17 (Summer): 217-29. 